\title{
Pectinatus, a New Genus of the Family Bacteroidaceae
}

\author{
S. Y. LEE, M. S. MABEE, AND N. O. JANGAARD \\ Research and Development Department, Adolph Coors Company, Golden, Colorado 80401
}

The properties of an anaerobic, rod-shaped bacterium having an unusual flagellar arrangement are described. The flagella emanate from only one side of the cell body and are not limited to the center portion as they are with selenomonads. The organism is a gram-negative, nonsporeforming mesophile producing acetic, propionic, and succinic acids and traces of lactic acid from glucose fermentation. The guanine-plus-cytosine content of the deoxyribonuleic acid is 39.8 $\mathrm{mol} \%$. The characteristics of this organism indicate that it belongs in none of the presently described genera. For this organism, we propose a new genus, Pectin. atus, and a new species, Pectinatus cerevisiiphilus, in the family Bacteroidaceae. The type strain, CCC B-1022, has been deposited in the American Type Culture Collection under the number 29359.

Few organisms are capable of growing in normal packaged beers because of the inherent selectivity brought about by $\mathrm{pH}$, alcohol content, hop residuals, and the lack of oxygen. The organisms generally referred to as "beer spoilage bacteria" are classified in the following genera: Acetobacter, Acetomonas, Lactobacillus, Pediococcus, and Zymomonas. Other bacteria, such as enterobacters and flavobacteria, are considered to be problems in the early brewing process but never in the final packaged product (1). During the course of routine identification work on bacteria in our brewery, we isolated an unusual bacterium capable of growing in beer. Unlike other common organisms, this organism was a strict anaerobe, producing no growth aerobically on solid media. Under anaerobic conditions it fermented several sugars. Scanning electron microscopy (SEM) revealed that flagella were attached on only one side of the cell body, giving the cells the appearance of hair combs. The unique features of this organism clearly indicated that it was not a "typical" beer bacterium, and to our knowledge an organism of this type has not, to date, been described in the literature. The purpose of this study was to present some of the morphological and biochemical characteristics of this new isolate and to determine its taxonomic position.

\section{MATERIALS AND METHODS}

Bacterial strain. Only one strain (CCC B-1022) was studied. It was isolated from beer which had been stored at $30^{\circ} \mathrm{C}$ for 30 days. Stock cultures were maintained by biweekly transfers in freshly prepared MRS lactobacilli broth (Difco) with minimal head space in the tube and with incubation at $30^{\circ} \mathrm{C}$. Between transfers, cultures were stored at $2^{\circ} \mathrm{C}$.

Media. For sugar utilization tests and for gas chromatographic analyses of volatile and nonvolatile fatty acids, prereduced media were used as described in the VPI Anaerobe Laboratory Manual (4). Cultures were grown in MRS lactobacilli broth (Difco) for determination of deoxyribonucleic acid (DNA) base composition, for preparation of cells for SEM photography, and for thin sections for electron microscopy. Thioglycolate agar with glucose (Difco) was used to obtain growth on solid media in Hungate roll tubes (5).

Biochemical tests. Peptone yeast extract, the basal medium, fortified with various carbon sources, was inoculated under oxygen-free $\mathrm{CO}_{2}$ atmosphere with 4 drops of an actively growing culture. After $48 \mathrm{~h}$ of incubation, the $\mathrm{pH}$ of the culture was determined with a combination $\mathrm{pH}$ electrode (4). Volatile and nonvolatile acids were determined by the procedures described in the VPI manual, using a Hewlett-Packard 5830-A chromatograph.

Determination of DNA base composition. The guanine-plus-cytosine content of the DNA of the test organism was determined by use of the method described by Schildkraut et al. (10).

Preparation of cells for SEM photography. An actively growing broth culture (18 to $24 \mathrm{~h}$ old) was harvested by centrifugation at $11,400 \times g$ for $15 \mathrm{~min}$. The supernatant was removed, and the cells were resuspended in sterile distilled water to yield a threeto-fourfold dilution of the original culture. The resulting suspension was slightly turbid. One drop of the dilute suspension was then placed on a grease-free glass cover slip, which was tilted so that the liquid ran slowly to the other end. To avoid breaking the flagella, a sterile glass pipette was used for transfer instead of a platinum loop. The cover slip was air dried in an empty petri dish with the lid slightly open. The airdried cover slip was then mounted on a standard SEM aluminum stub by using $3 \mathrm{M}$ double-coated tape. The underside (stub side) as well as the edges of the cover slip were painted with silver conducting paint (no. 211 GE Electronics, Rockford, Ill.) so that a continuous conductive path from cover-slip edge to stub was established. Mounted samples were coated with a gold-palladium amalgam ( $60 \%$ gold- $40 \%$ palladium) in a Denton DU 502 vacuum evaporator at $6 \times 10^{-6}$ torr pressure. A current of $16 \mathrm{~A}$ was applied to the filament 
(20-mil-diameter tungsten) for $30 \mathrm{~s}$, and then the current was raised to $22 \mathrm{~A}$ for an additional $30 \mathrm{~s}$. The average filament-to-sample distance was $10.0 \mathrm{~cm}$. During coating, the samples were on a rotating, tilting omni stage electrically rotated at $40 \mathrm{rpm}$. Coated samples were examined with an ETC Autoscan SEM at $35^{\circ}$ tilt, $20 \mathrm{kV}$ accelerating voltage, and with secondary electron imaging. Additionally, a drop of suspension air dried on a cover slip was flagella stained by the Conn and Wolfe method (3) and was then coated with gold-palladium, as described above, for a clearer view of the flagellar arrangement.

Thin sections and electron microscopy. Thin sections were prepared by the method described by Higgins in the Handbook of Microbiology (7). Sections were photographed with a Hitachi model HU-12 elec- tron microscope, with an accelerating voltage of 75,000 $\mathrm{kV}$.

\section{RESULTS}

Morphology. The cells of strain CCC B-1022 are slightly curved, gram-negative rods with rounded ends, 0.7 to $0.8 \mu \mathrm{m}$ by 2.0 to $32 \mu \mathrm{m}$ or longer in older cells (Fig. 1); they occur singly, sometimes in pairs, and only rarely in chains. Shorter, younger cells do not show a helical shape, but the elongated older cells tend to form helices. After the culture had passed the stationary and declining phases, round cell forms were often observed, and the number of these in-

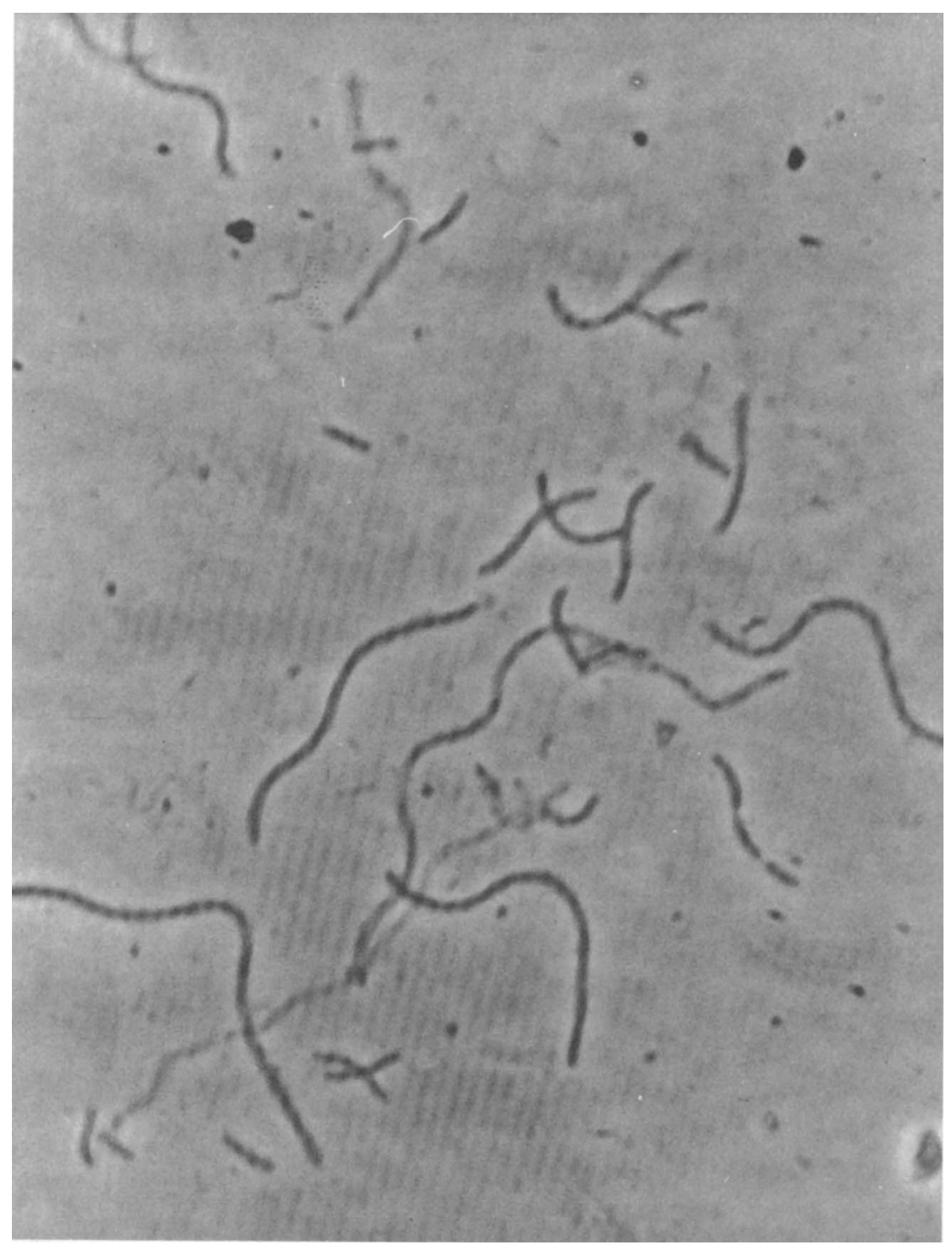

FIG. 1. Elongated cells of strain CCC B-1022 under phase-contrast microscopy. $\times 1,200$. 
creased with the time of incubation (Fig. 2). These globular forms are believed to be identical with the spheroplasts of selenomonads (6). Young cells move very actively, giving the appearance of an " $X$ " shape as they swim. Older and longer cells appear to have a snakelike motion as they move.

The most unique morphological feature of this organism is the flagellar arrangement. SEM micrographs reveal that the flagella emanate from only one side of a cell (Fig. 3). Flagella are not limited to the center portion of the concave side of the cell as they are in the genus Selenomonas. The number of flagella per cell seems to depend upon the cell size and its condition, but generally they range from 10 to 23 or more. The flagellar wavelength is about $2 \mu \mathrm{m}$. The fact that flagella emanate from only one side of cells oriented in different directions (Fig. 4) indicates that this unique flagellar arrangement is not a result of sample preparation. The flagella stain-gold-palladium coating preparation of this organism clearly shows the attachment of the flagella along the side of the cell body (Fig. 5 and 6 ).

Ultrastructure of the cell. Examination of a thin section of a cell of strain CCC B-1022 (Fig. 7) revealed a multilayered cell wall typical of gram-negative bacteria (8). The outer double layer of the cell wall appears to have a profile characteristic of lipopolysaccharide and lipoprotein as described by Murray et al. (9). Figure 8 shows a number of broken flagella still attached at only one side of the cell body.

Cultural characteristics. No growth was obtained on agar plates under aerobic conditions or under $98 \% \mathrm{CO}_{2}$. By the Hungate roll tube technique (5) with thioglycolate agar, colonies developed after 3 to 4 days of incubation at $30^{\circ} \mathrm{C}$. Colonies were circular, entire, low convex to pulvinate white, glistening, and opaque. The

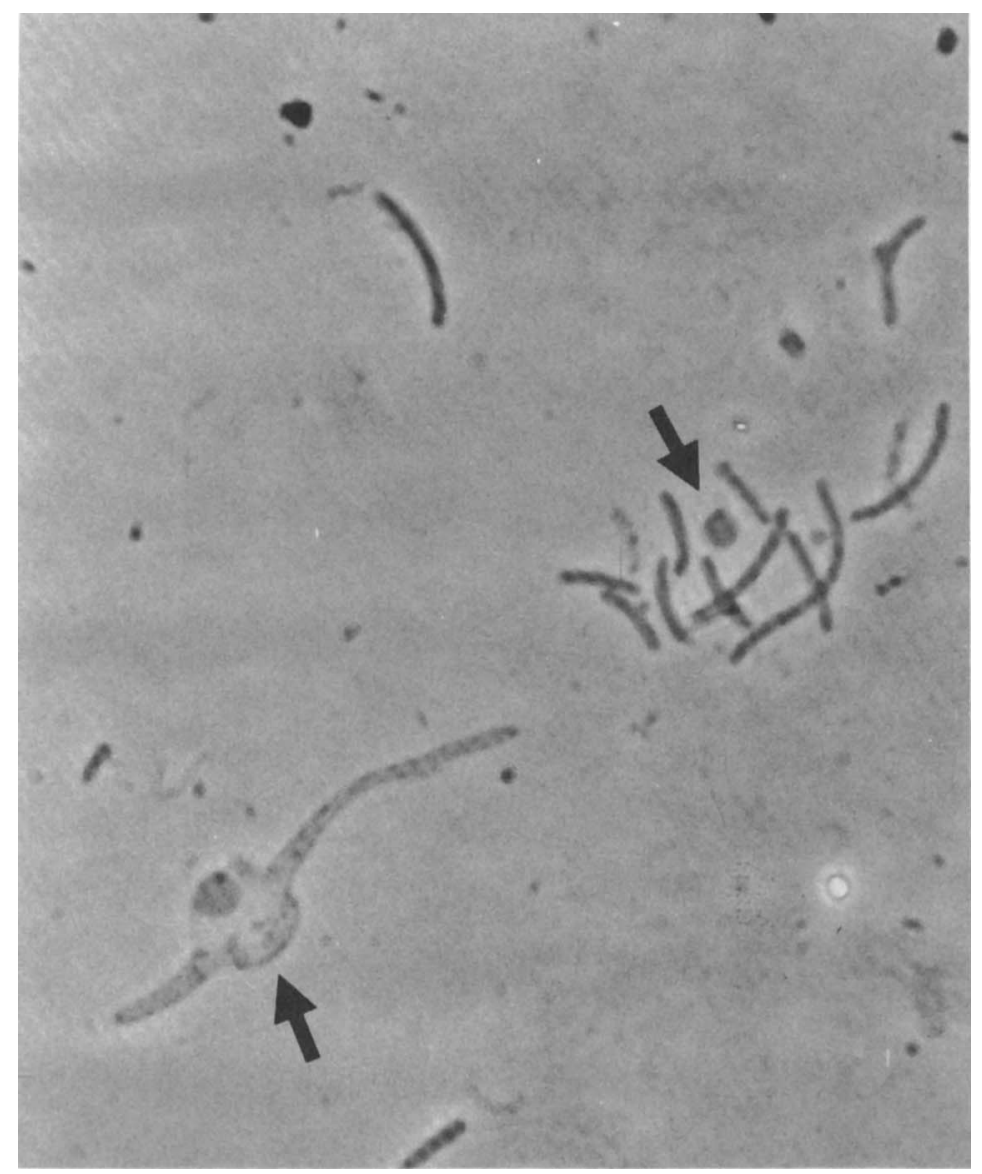

Fig. 2. Globular forms (arrows) of strain CCC B-1022 under phase-contrast microscopy. $\times 1,200$. 


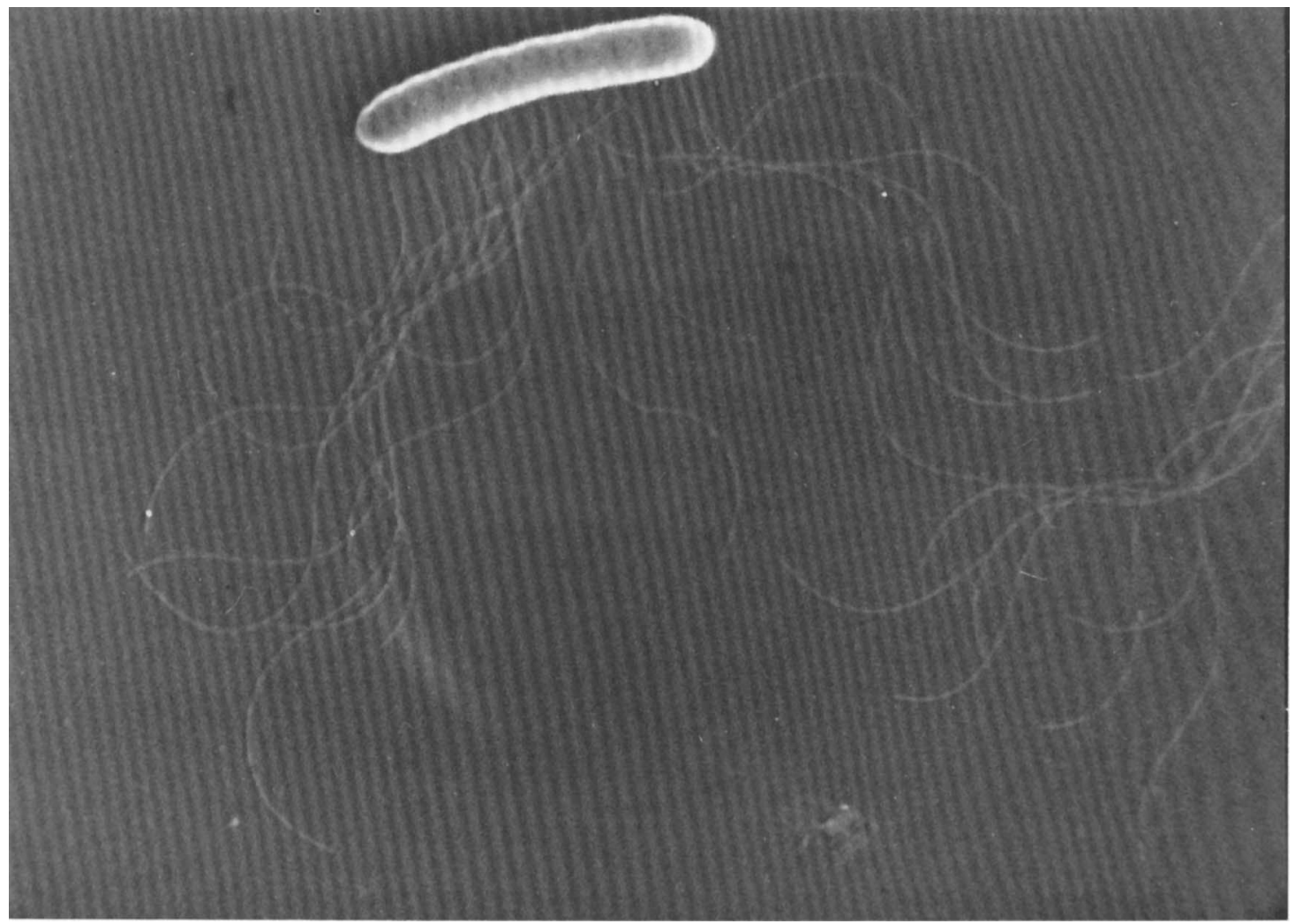

FIG. 3. SEM micrograph illustrating flagella of strain CCC B-1022. $\times 13,680$.

organism grew fairly well in any broth medium containing fermentable sugars. With a $2 \%$ inoculum, growth was obtained in freshly prepared aerobic broth (i.e., MRS lactobacilli broth) tubed with a minimum of head space. Anaerobic conditions were not required for growth in broth cultures. The cells were actively motile in young (18- to 24-h-old) cultures, but they slowly lost motility as they grew older and eventually lost all motility.

Physiological and biochemical characteristics. The organism is an anaerobic mesophile. It grows between 15 and $40^{\circ} \mathrm{C}$, with optimum growth occurring at about $32^{\circ} \mathrm{C}$. It produced acid from adonitol, arabinose, cellobiose, dulcitol, erythritol, fructose, galactose, glucose, glycerol, lactate, maltose, mannitol, mannose, rhamnose, and ribose (Table 1). Amygdalin, milk, raffinose, salicin, sorbitol, sorbose, sucrose, trehalose, and xylose were not fermented. Nitrite was not produced from nitrate, and starch was not hydrolyzed. Acetic, propionic, succinic, and lactic acids were produced from glucose, and acetic, propionic, and succinic acids were pro- duced from lactate. Volatile and nonvolatile fatty acid products are shown in Table 2 and Fig. 9 through 12. Catalase was not produced.

DNA base composition. The guanine-pluscytosine content of the DNA of this organism was found to be $39.8 \mathrm{~mol} \%$.

\section{DISCUSSION}

The most striking structural feature of this organism is the unusual arrangement of the flagella. Members of the genus Selenomonas most closely resemble this organism; however, a "tuft" arrangement of flagella is described for Selenomonas. Due to the differences between this species and those in previously described anaerobic genera (see Tables 3 and 4), we place this species in a new genus, Pectinatus (Pec.ti.na tus. L. part. adj. pectinatus combed; M.L. mas. n. Pectinatus combed [bacteria]). The type species is $P$. cerevisiiphilus sp. nov. (ce.re.vi.si.i phi.lus. L. n. cerevisia beer; Gr. adj. philus loving; M.L. adj. cerevisiiphilus beer-loving), of which the type strain is CCC B-1022 (a culture of this strain has been deposited in the American Type Culture 


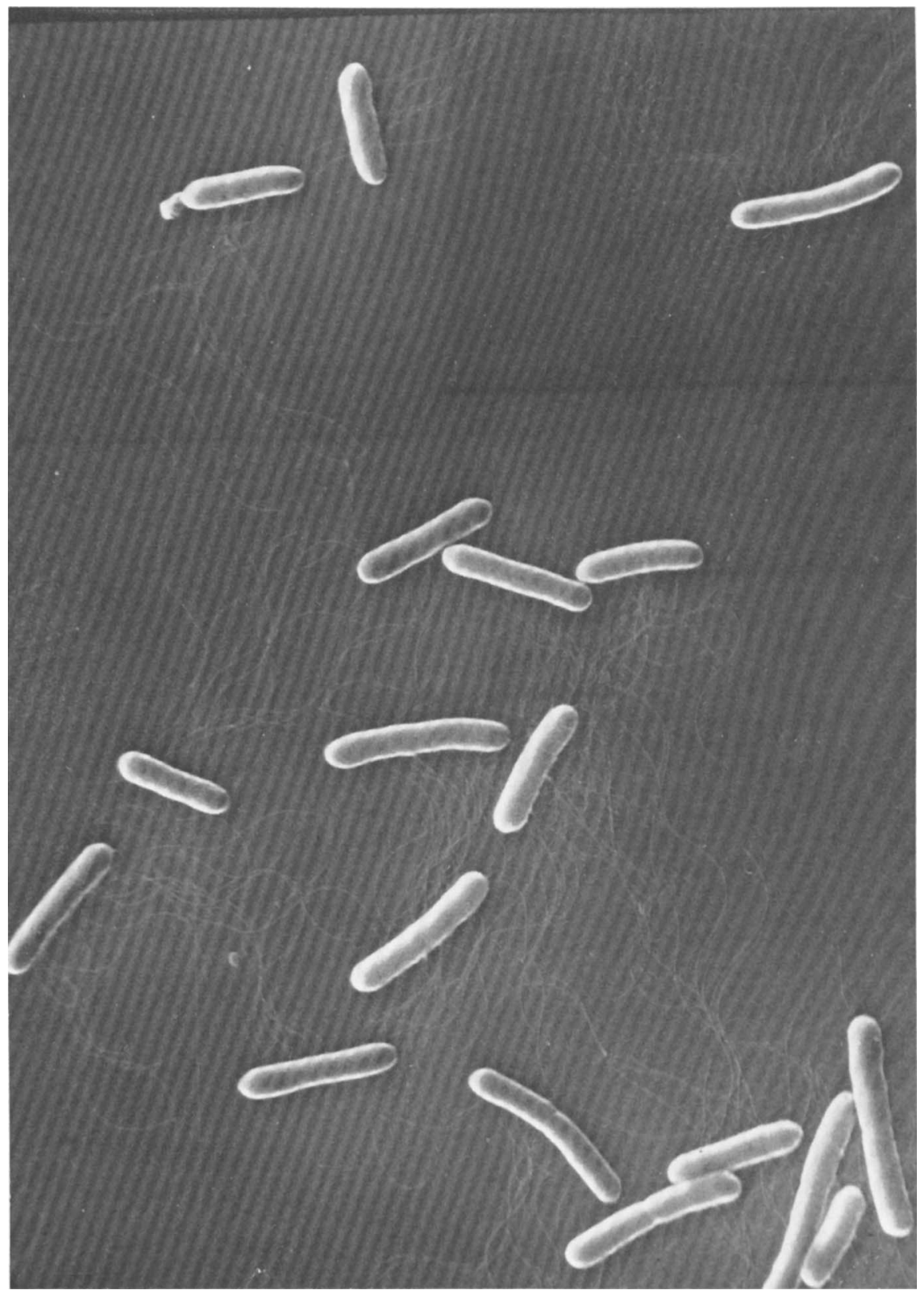

Fig. 4. SEM micrograph of lateral flagellar arrangement in a 48-h-old culture of strain CCC B-1022. $\times 7,240$. 


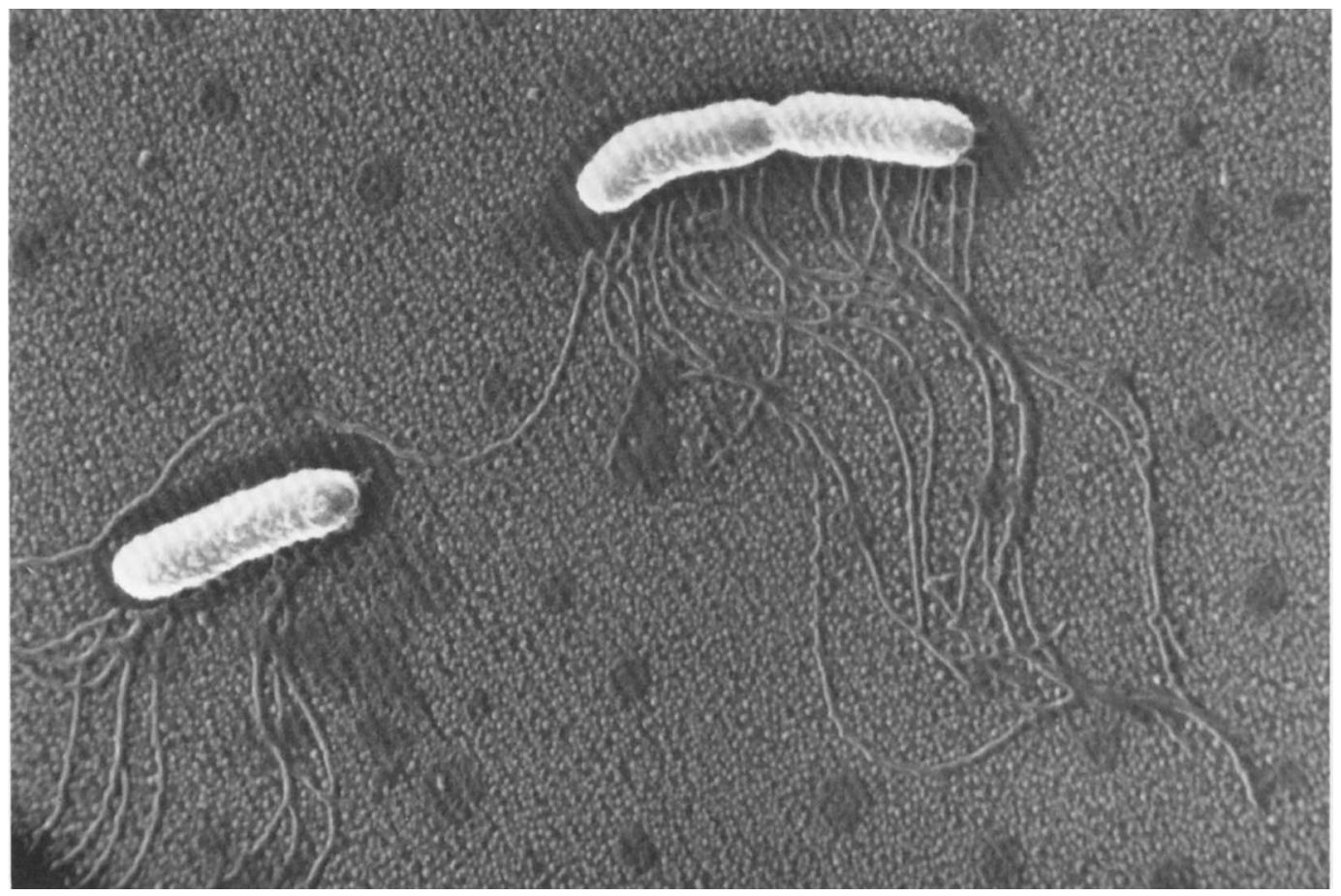

FIG. 5. SEM micrograph of a flagella stain-amalgam-coated preparation of strain CCC B-1022. $\times 12,813$.

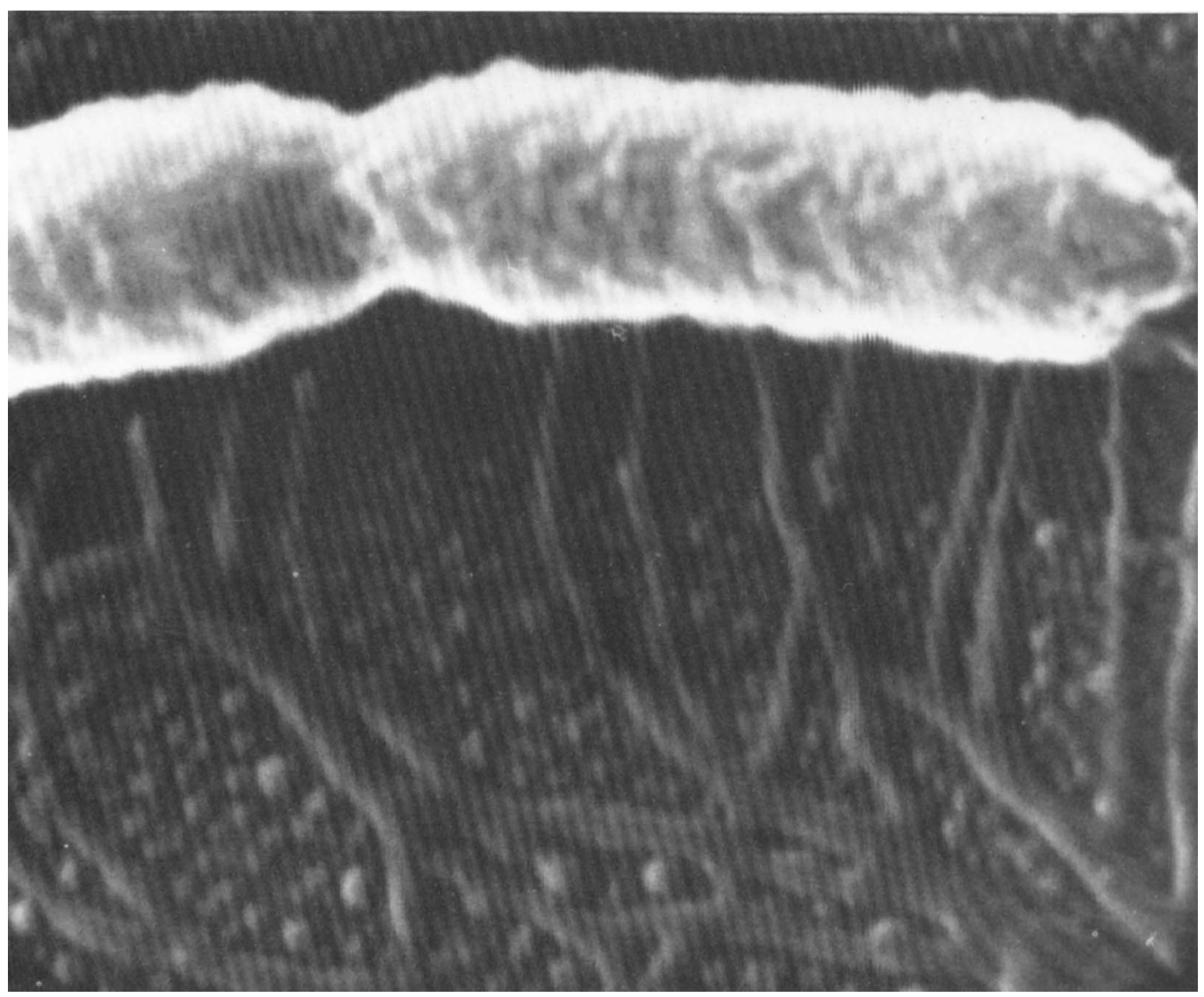

FIG. 6. SEM micrograph of a flagella stain-amalgam-coated preparation of strain CCC B-1022. $\times 60,164$. 


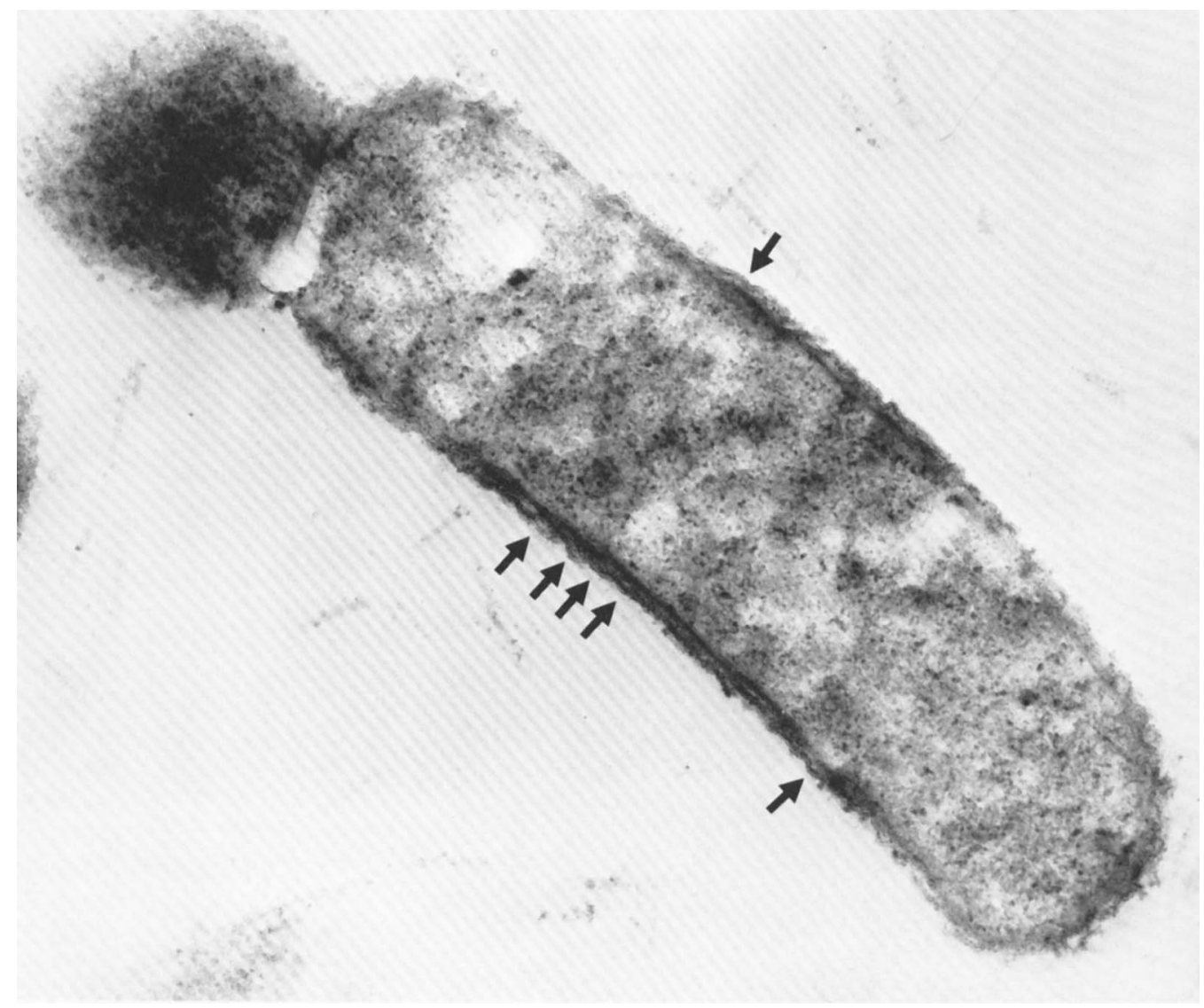

Fig. 7. Thin section of a typical cell of strain CCC B-1022 illustrating irregular, undulating cell wall layers (arrows). $\times 44,250$. 


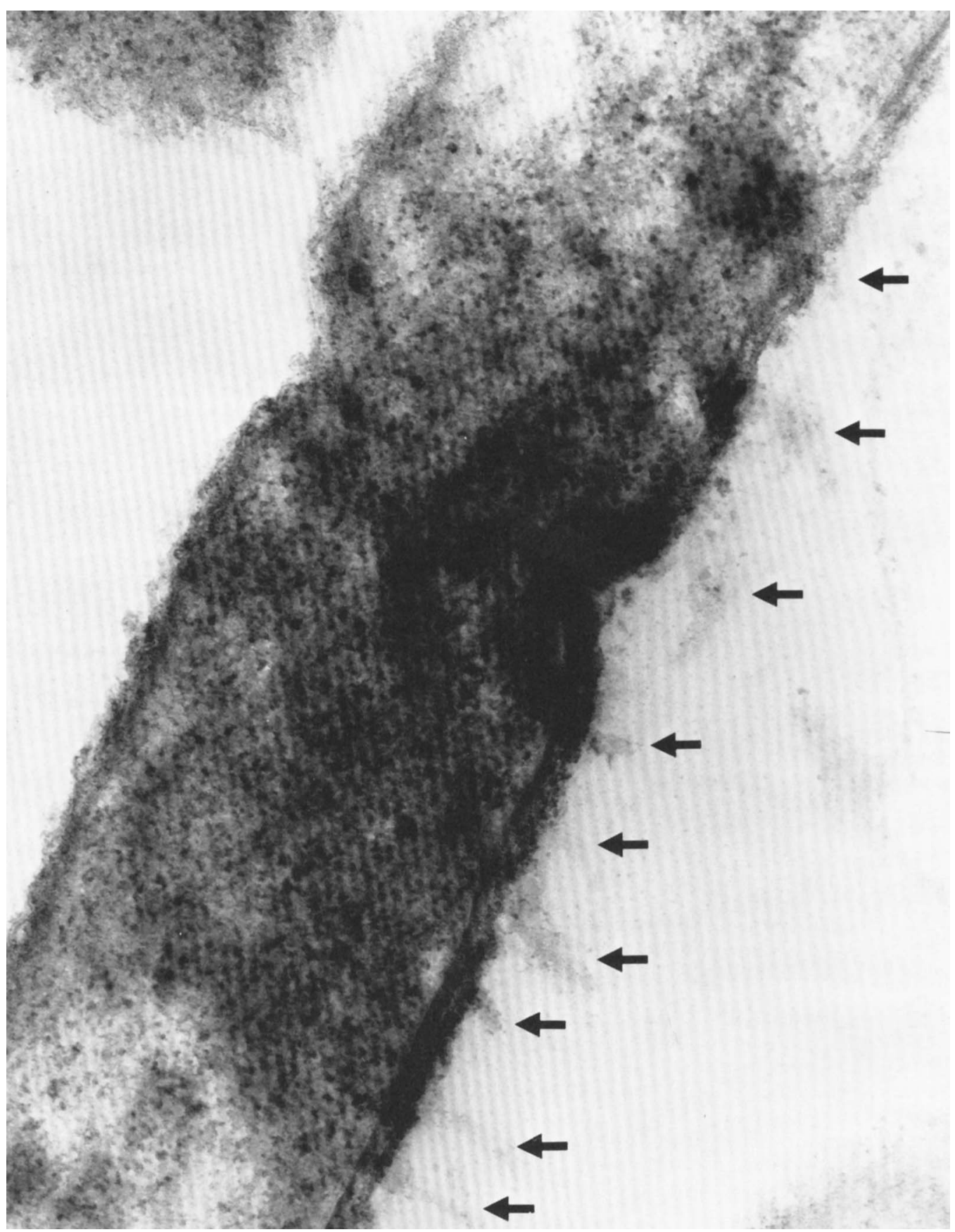

FIG. 8. Thin section of a typical cell of strain CCC B-1022 illustrating broken flagella along one side of the cell. $\times 121,675$. 
TABLE 1. Biochemical reactions of strain CCC B-1022

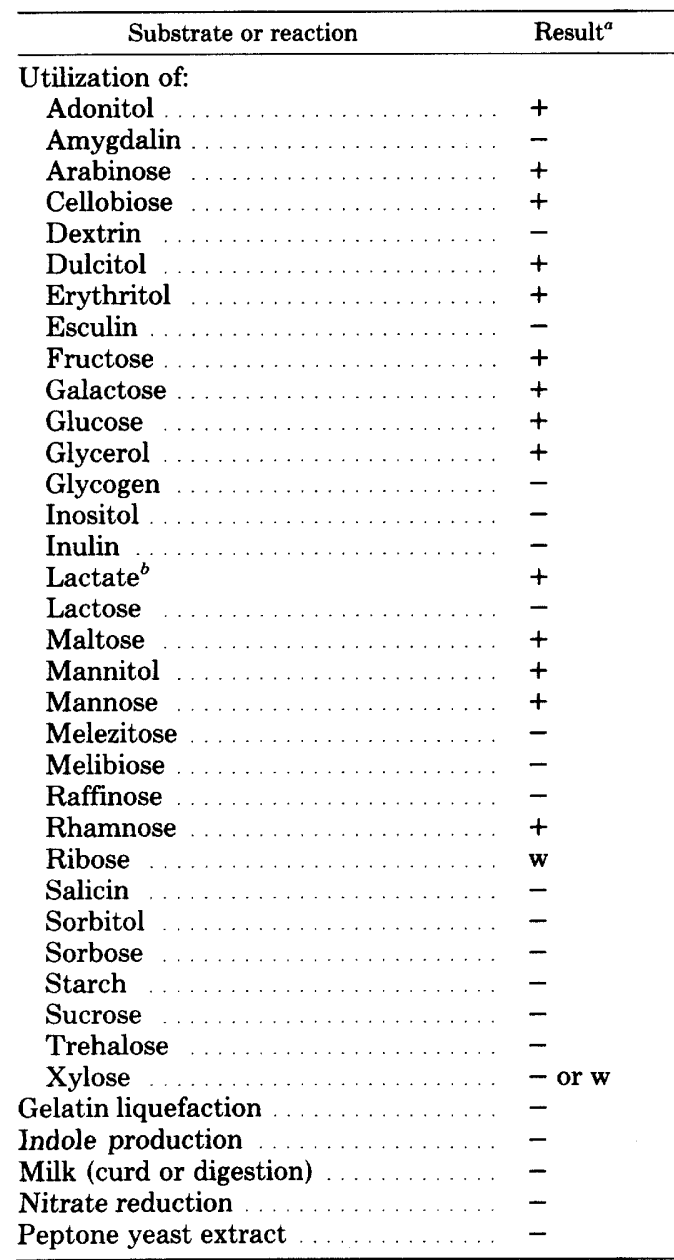

${ }^{a}$ Symbols:,$+ \mathrm{pH}$ below 5.5 in carbohydrate cultures (positive reaction);,$- \mathrm{pH}$ above 6.0 (negative reaction); $\mathrm{w}, \mathrm{pH}$ between 5.5 and 6.0 (weak reaction).

${ }^{b}$ Since the measurement of $\mathrm{pH}$ cannot be used to determine lactate utilization, gas chromatography was used to determine the by-products produced.

Collection [ATCC] under the number 29359). Because only a single strain (CCC B-1022) of this new species has been isolated to date, the description given above for this strain also serves as the species description. Obviously the description will have to be modified as more isolates are described. The same is true of the generic description, which follows.

Pectinatus gen. nov. Slightly curved rods, with rounded ends, occurring singly, in pairs, and only rarely in short chains. Shorter, younger cells do not show a helical shape, but the elon- gated older cells tend to form helices. Motile by means of flagella which emanate from only one side of a cell. The attachment of the flagella is not limited to the central portion of the concave side of the cells as it is in the genus Selenomonas. Growth occurs between 15 and $40^{\circ} \mathrm{C}$, with optimum growth occurring at about $32^{\circ} \mathrm{C}$. Acetic, propionic, succinic, and lactic acids are produced from glucose, and propionic and succinic acids are produced from lactate. Nitrite is not produced from nitrate, and starch is not hydrolyzed. Strictly anaerobic. Catalase is not produced. First isolated from spoiled beer, but the habitat is not known.

The type species is Pectinatus cerevisiiphilus.

The general staining characteristics, cellular morphology (Fig. 1 and 2), and anaerobic requirements of the organism described here most closely resemble those of members of two families: Bacillaceae and Bacteroidaceae (2). However, the inability to demonstrate spore production by this organism was considered preliminary justification to eliminate it from membership in the family Bacillaceae. The most significant structural feature of this organism is its unique lateral flagellar arrangement. Among members of the family Bacteroidaceae, none of the three currently recognized genera (2) exhibits this structural feature. Of the gram-negative, anaerobic bacteria of uncertain affiliation (Desulfovibrio, Butyrivibrio, Succinivibrio, Succinimonas, Lachnospira, and Selenomonas) (2), members of the genus Selenomonas possess a flagellar arrangement which most closely resembles that of this organism. The important morphological difference between the selenomonads and this organism, however, is the "tuft" arrangement of the flagella of the selenomonads (6). The isolate described here clearly possesses a comblike flagellar arrangement along the long axis of the cell (Fig. 3 to 6, and 8). Cells were gram negative to gram variable, and the electron micrographs (Fig. 7 and 8) taken of thin sections of a cell indicate irregular, undulating cell wall layers that are usually associated with gramnegative organisms.

Strain CCC B-1022 is capable of fermenting a variety of sugars (Table 1). Gas chromatographic analysis of the products of sugar fermentation indicate that the organism produces acetic, propionic, succinic, and lactic acids from glucose (Table 2). There was no evidence of butyric acid production from any of the sugar substrates tested. The DNA base composition of the isolate is $39.8 \mathrm{~mol} \%$ guanine plus cytosine, whereas members of the genus Selenomonas are reported to have a guanine-plus-cytosine value of 54 or $60 \mathrm{~mol} \%$ (Table 4). A summary of some of the 
TABLE 2. Volatile and nonvolatile fatty acids produced from darious fermentable carbon sources by strain CCC B-1022

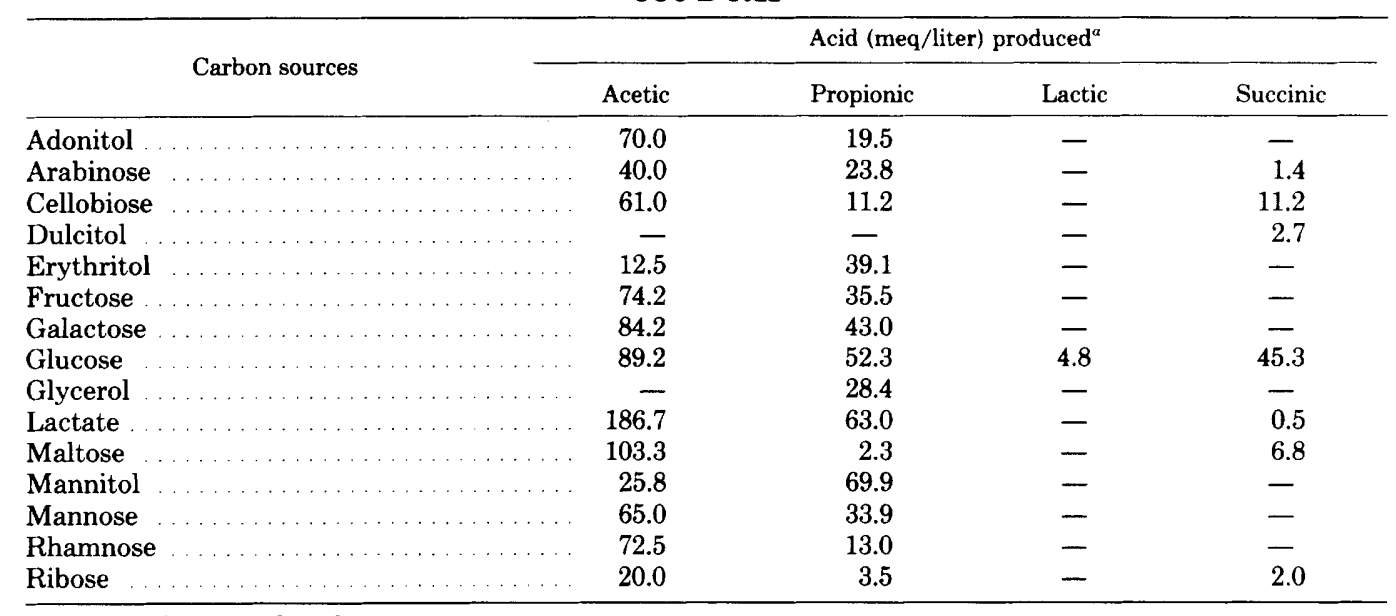

${ }^{a}-$, Acid not produced.

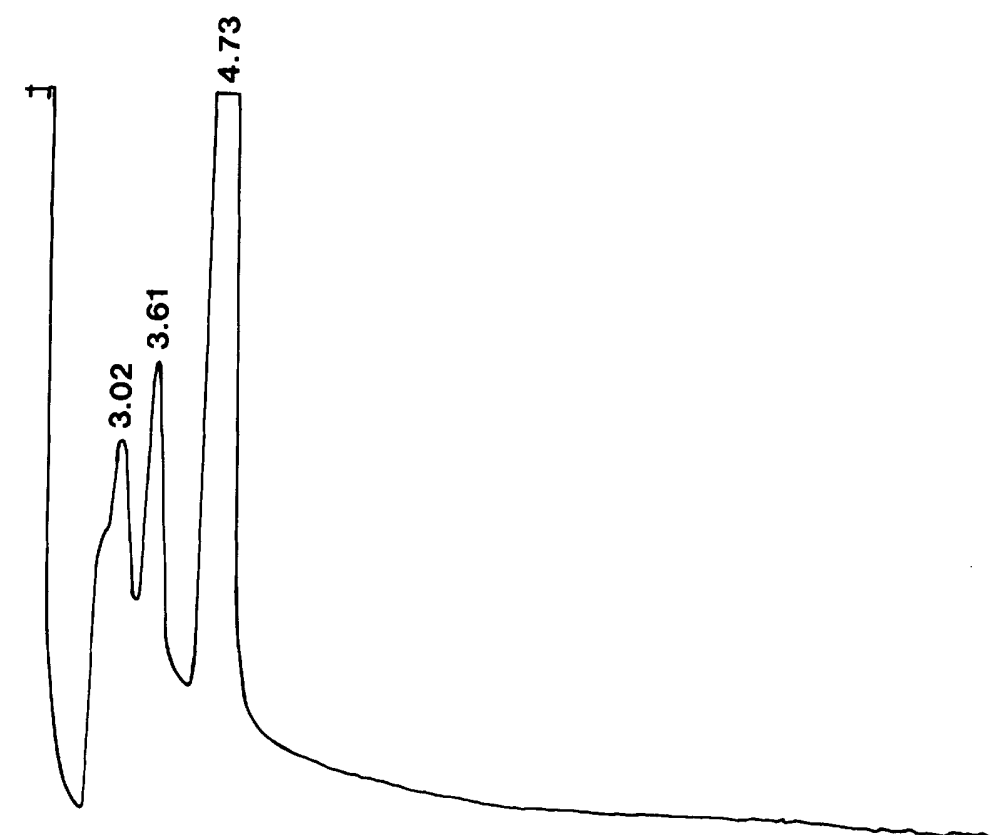

FIG. 9. Typical chromatogram of volatile fatty acids produced by strain CCC B-1022 in peptone-yeast extract-glucose medium. Acetic acid retention time $=3.61 \mathrm{~min}$. Propionic acid retention time $=4.73 \mathrm{~min}$.

major characteristics of strain CCC B-1022 and closely related organisms is presented in Table 3 . In most cases, these organisms possess more than one major characteristic which differs from the characteristics of the new isolate described here. Only three of the organisms listed in Table 3 demonstrate lateral flagellation of any kind:
Lachnospira, Selenomonas, and the new isolate. End products of glucose fermentation indicate that lachnospiras are ethanol producers. Preliminary studies on our isolate (gas chromatography and alcohol dehydrogenase tests) indicated no ethanol production from glucose.

In Table 4, the differences between seleno- 


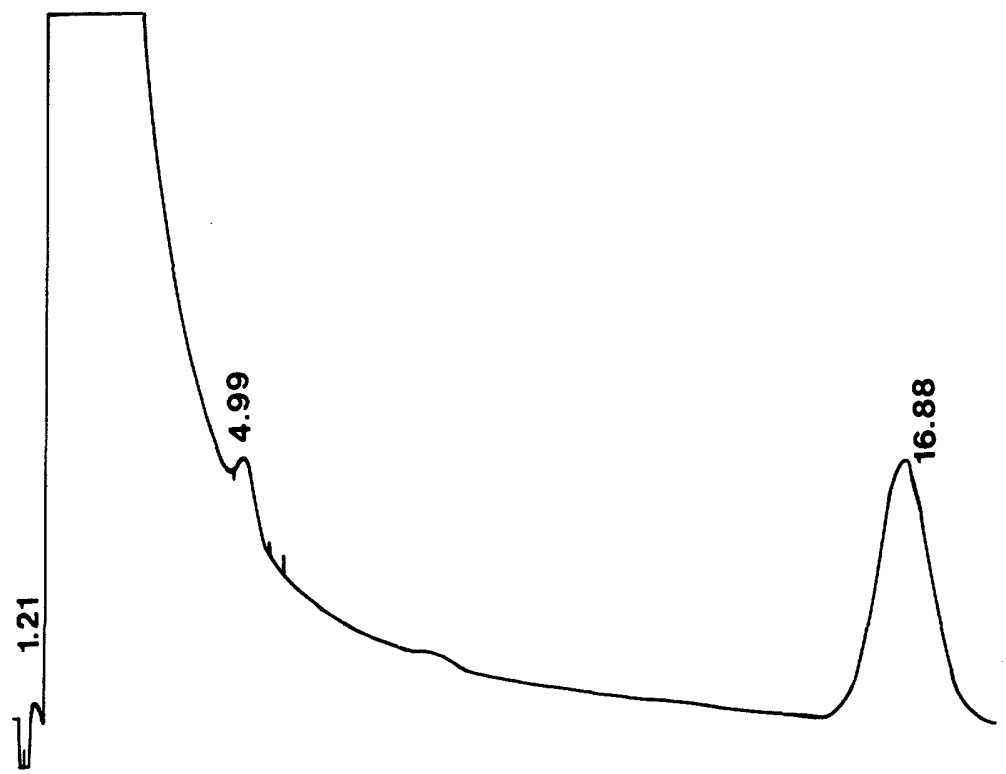

FIG. 10. Typical chromatogram of methylated (nonvolatile) fatty acids produced by strain CCC B-1022 in peptone-yeast extract-glucose medium. Lactic acid retention time $=4.99$ min. Succinic acid retention time $=$ $16.88 \mathrm{~min}$.

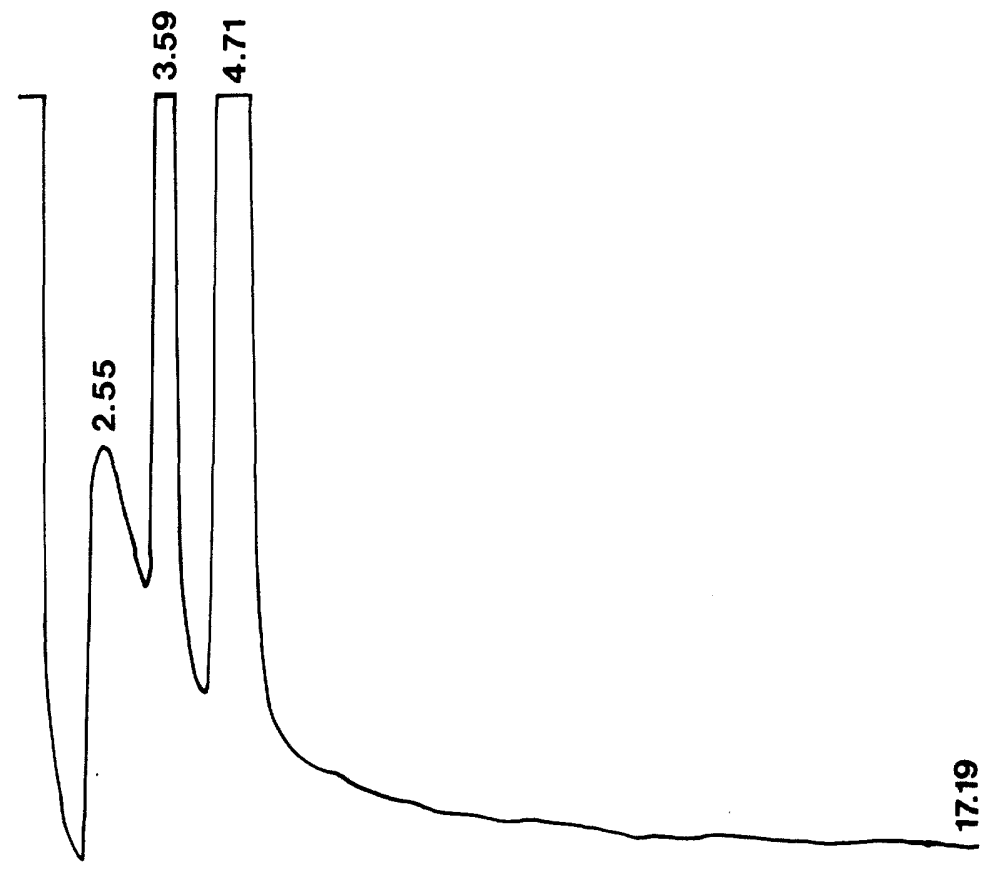

Fig. 11. Typical chromatogram of volatile fatty acids produced from lactate by strain CCC B-1022. Acetic acid retention time $=3.59 \mathrm{~min}$. Propionic acid retention time $=4.71 \mathrm{~min}$. 


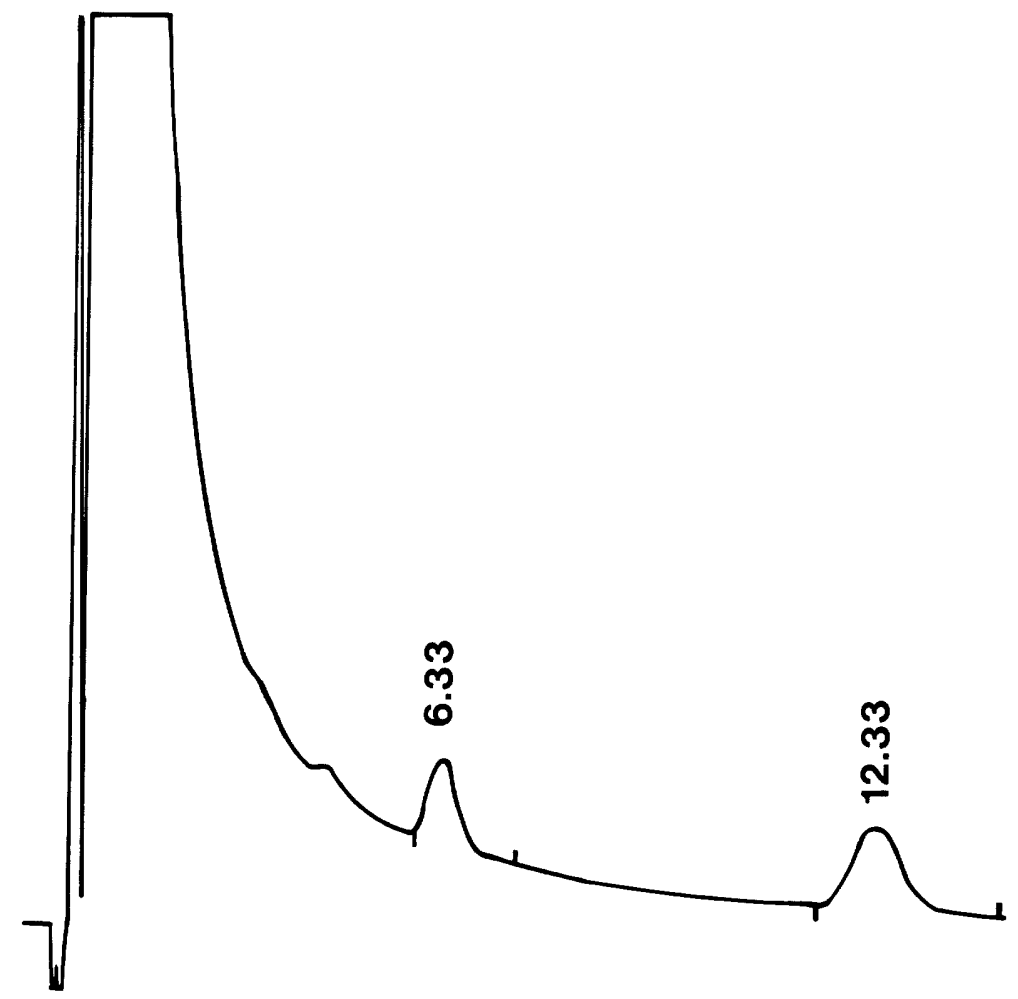

FIG. 12. Typical chromatogram of methylated (nonvolatile) fatty acids produced from lactate by strain CCC B-1022. Succinic acid retention time $=12.33 \mathrm{~min}$. Propionic acid (background due to excess amount in medium) retention time $=6.33 \mathrm{~min}$.

TABLE 3. Characteristics useful in differentiating strain CCC B-1022 from other anaerobes

\begin{tabular}{|c|c|c|c|c|}
\hline Taxon & $\begin{array}{l}\text { Arrangement } \\
\text { of flagella }\end{array}$ & $\begin{array}{l}\text { Spore } \\
\text { produc- } \\
\text { tion }\end{array}$ & $\begin{array}{c}\text { Glucose } \\
\text { by-products }\end{array}$ & $\begin{array}{l}\mathrm{G}+\mathrm{C} \\
\text { ratio } \\
(\mathrm{mol} \%)\end{array}$ \\
\hline Clostridium & $\begin{array}{l}\text { Peritrichous (if flagella oc- } \\
\text { cur) }\end{array}$ & + & & $23-43$ \\
\hline Bacteroides & None or peritrichous & - & $\begin{array}{l}\text { Combinations of succinic, } \\
\text { lactic, acetic, formic, and } \\
\text { propionic acids }\end{array}$ & $40-55$ \\
\hline Fusobacterium & None or peritrichous & - & Butyric acid & $26-34$ \\
\hline Leptotrichia & None & - & Lactic acid & $31-34$ \\
\hline Desulfovibrio & Polar & - & Not known & $46-61$ \\
\hline Butyrivibrio . & Polar (single flagellum) & - & Lactic and butyric acids & Not known \\
\hline Succinivibrio & Polar (single flagellum) & - & $\begin{array}{l}\text { Succinic, acetic, formic, and } \\
\text { lactic acids }\end{array}$ & Not known \\
\hline Succinimonas & Polar (single flagellum) & - & Succinic and acetic acids & Not known \\
\hline Lachnospira & Subterminal to lateral & - & $\begin{array}{l}\text { Ethanol, lactic, formic, and } \\
\text { acetic acids }\end{array}$ & Not known \\
\hline Selenomonas & Lateral (tufted) & - & $\begin{array}{l}\text { Acetic, propionic, and lactic } \\
\text { acids }\end{array}$ & $53-61$ \\
\hline Strain CCC B-1022 & Lateral (comblike) & - & $\begin{array}{l}\text { Acetic, propionic, succinic, } \\
\text { and lactic acids }\end{array}$ & 39.8 \\
\hline
\end{tabular}

monads and the new isolate with respect to cell morphology, flagellation, DNA base composition, and substrate utilization are readily apparent.
The properties of the new, anaerobic, gramnegative, mesophilic rod described here are, in our opinion, sufficient to warrant placing the organism in a new genus. 
TABLE 4. Characteristics useful for differentiating between selenomonads and Pectinatus cerevisiiphilus sp. nov. ${ }^{a}$

\begin{tabular}{|c|c|c|c|}
\hline Characteristic & $\begin{array}{l}\text { Selenomonas } \\
\text { ruminantium }\end{array}$ & $\begin{array}{l}\text { Selenomonas } \\
\text { sputigena }\end{array}$ & $\begin{array}{l}\text { Pectinatus } \\
\text { cerevisiiphilus } \\
\text { sp. nov. }\end{array}$ \\
\hline$\ldots \ldots \ldots \ldots$ & Crescent moon & Crescent moon & $\begin{array}{l}\text { Slightly curved rod } \\
\text { with round ends }\end{array}$ \\
\hline Cell size $(\mu \mathrm{m})$ & $0.9-1.1$ by $3.5-6.0$ & $0.9-1.1$ by $3.0-5.5$ & $\begin{array}{l}0.7-0.8 \text { by } 2.0-32 \text { or } \\
\text { longer }\end{array}$ \\
\hline Flagella location & $\begin{array}{l}\text { Tuft in the center of } \\
\text { the concave side }\end{array}$ & $\begin{array}{l}\text { Tuft in the center of } \\
\text { the concave side }\end{array}$ & $\begin{array}{l}\text { Only one side (con- } \\
\text { cave), but not as a } \\
\text { tuft }\end{array}$ \\
\hline No. of flagella per cell & 16 & 16 & $10-23$ or more \\
\hline DNA base ratio (mol\% $\mathrm{G}+\mathrm{C}$ ) & $54.0 \pm 0.8$ & $60.6 \pm 0.8$ & 39.8 \\
\hline Glucose fermentation products $\ldots \ldots \ldots \ldots$ & $\begin{array}{l}\text { Propionic, acetic, and } \\
\text { lactic acids }\end{array}$ & $\begin{array}{l}\text { Propionic and acetic } \\
\text { acids }\end{array}$ & $\begin{array}{r}\text { Acetic, propionic, suc- } \\
\text { cinic, and lactic acids }\end{array}$ \\
\hline \multicolumn{4}{|l|}{ Utilization of: } \\
\hline Erythritol & - & - & $\mathbf{a}$ \\
\hline$\ldots \ldots \ldots \ldots \ldots \ldots \ldots$ & + & + & - \\
\hline Lactose $\ldots \ldots \ldots \ldots \ldots \ldots \ldots \ldots$ & $\mathbf{v}$ & $\mathbf{a}$ & - \\
\hline Melibiose $\ldots \ldots \ldots \ldots \ldots \ldots \ldots \ldots$ & $\mathbf{a}_{\mathbf{w}}$ & $\mathbf{a}_{\mathbf{w}}$ & - \\
\hline Raffinose $\ldots \ldots \ldots \ldots \ldots \ldots \ldots$ & $\mathbf{v}$ & a & - \\
\hline Sucrose $\ldots \ldots \ldots \ldots \ldots \ldots \ldots \ldots \ldots \ldots \ldots \ldots$ & $\mathbf{a}_{\mathbf{w}}$ & $\mathbf{a}_{\mathbf{w}}$ & - \\
\hline Xylose $\ldots \ldots \ldots \ldots \ldots \ldots \ldots \ldots$ & a & $\mathbf{a}$ & - \\
\hline Milk $\ldots \ldots \ldots \ldots \ldots \ldots \ldots \ldots$ & c & c & - \\
\hline Adonitol $\ldots \ldots \ldots \ldots \ldots \ldots \ldots$ & - & - & $\mathbf{w}$ \\
\hline
\end{tabular}

\footnotetext{
${ }^{a}$ Symbols: + , positive reaction for 90 to $100 \%$ of the strains tested; -, negative reaction for 90 to $100 \%$ of the strains tested; a, strong acid production (pH 5.5 or below); $a_{w}$, most strains produce acid, some weakly; c, curd produced in milk; v, variable acid production (strains maybe either + or - ); w, weak acid production (pH 5.5-6.0).
}

\section{ACKNOWLEDGMENTS}

We thank the Adolph Coors Co. for its permission to publish this paper. We also thank Charles Maurer for his help in preparing the scanning electron micrograph pictures and Dave Schisler for the gas chromatographic work. We would. especially like to thank Manley Mandel, Anderson Hospital,. Section of Molecular Biology, Houston, Tex., for his work in performing the DNA base composition analysis. Our appreciation is also extended to M. P. Bryant, University of Illinois, and L. V. Holdeman, VPI Anaerobe Laboratory, for their helpful suggestions and constructive criticisms during the preparation of the manuscript. The thin-section electron micrograph was prepared by Frank Lavac, Department of Microbiology, Colorado State University, Fort Collins, Colo.

\section{REPRINT REQUESTS}

Address reprint request to: S. Y. Lee, Research and Development Department, Adolph Coors Co., Golden, CO 80401.

\section{LTERATURE CITED}

1. Ault, R. G., and P. Newton. 1971. p. 164-197. In W. P. $K$. Findlay (ed.), Spoilage organisms in brewing in modern brewing technology. Macmillan Publishing Co., Inc., New York.

2. Buchanan, R. E., and N. E. Gibbons (ed.). 1974. Bergey's manual of determinative bacteriology, 8th ed., p. 384-426. The Williams \& Wilkins Co., Baltimore.
3. Conn, H. J., and G. E. Wolfe. 1938. Flagella staining as a routine test for bacteria. J. Bacteriol. 36:517-520.

4. Holdeman, L. V., and W. E. C. Moore (ed.). 1973. Anaerobe laboratory manual, 2nd ed. Virginia Polytechnic Institute and State University, Blacksburg.

5. Hungate, R. E. 1970. A roll tube method for cultivation of strict anaerobes, p. 117. In J. R. Norris and D. W. Ribbons (ed.), Methods in microbiology, vol. 3B. Academic Press Inc., New York.

6. Kingsley, V. V., and J. Hoeniger. 1973. Growth, structure and classification of Selenomonas. Bacteriol. Rev. 37:479-521.

7. Laskin, A. I., and H. A. Lechevalier (ed.). 1973. Handbook of microbiology, vol. 1, Organismic microbiology, p. 686-689. CRC Press, Cleveland, Ohio.

8. Lautrop, H., A. Reyn, and A. A. Birch-Andersen. 1964. A comparative electron microscope study of the cell walls of gram-negative bacteria. Proceedings of the XIV Scandinavian Congress of Pathology and Microbiology, Oslo.

9. Murray, R. G. E., P. Steed, and H. E. Elson. 1965. The location of the mucopeptide in sections of the cell wall of Escherichia coli and other gram-negative bacteria. Can. J. Microbiol. 11:547-560.

10. Schildkraut, C. L., J. Marmur, and P. Doty. 1962. Determination of the base composition of deoxyribonucleic acid from its buoyant density in $\mathrm{CsCl}$. J. Mol. Biol. 4:430-443. 